\title{
A new species of the genus Neocbirosia Malloch, 1917 (Diptera, Scathophagidae) from Serbia
}

\author{
Новый виА рода Neochirosia Malloch, 1917 \\ (Diptera, Scathophagidae) из Сербии
}

\author{
A.L. Ozerov ${ }^{1}$, M.G. Krivosheina ${ }^{2}$

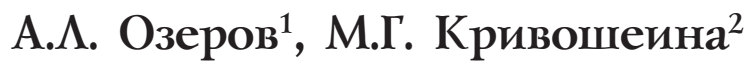

\begin{abstract}
${ }^{1}$ Zoological Museum, Moscow Lomonosov State University, Bol’shaya Nikitskaya 6, Moscow 125009, Russia. E-mail: ozerov2455@rambler.ru

1 Зоологический музей, Московский государственный университет им. М.В. Ломоносова, Большая Никитская ул., 6, Москва 125009, Россия.

${ }^{2}$ A.N. Severtzov Institute of Ecology and Evolution, Russian Academy of Sciences, 119071 Moscow, Russia, e-mail: dipteramarina@rambler.ru
\end{abstract} \\ ${ }^{2}$ Институт проблем экологии и эволюции им. А.Н.Северцова РАН, Ленинский проспект, 33, Москва 119071, Россия.
}

KEYWORDS: Diptera, Scathophagidae, Neochirosia, new species, Serbia.

КЛЮЧЕВЫЕ СЛОВА: Diptera, Scathophagidae, Neochirosia, новый вид, Сербия.

ABSTRACT. A new species, Neochirosia nikita sp.n. (Diptera, Scathophagidae), is described from Serbia. One new synonym is established: Mirekiana Šifner, 2012 is a new synonym of Neochirosia Malloch, 1917.

РЕЗЮМЕ. С территории Сербии описан новый вид из семейства Scathophagidae - Neochirosia nikita sp.n. Установлено, что родовое название Mirekiana Šifner, 2012 есть новый младший синоним Neochirosia Malloch, 1917.

\section{Introduction}

One new species from the genus Neochirosia Malloch, 1917 was discovered as a result of the examination of dung flies (Diptera, Scathophagidae) collected by Dr. Nikita Vikhrev in May 2015 in Serbia. The description of this species is given below. Holotype and paratypes of the new species are kept in the collection of Zoological Museum of Moscow State University (ZMUM).

Neochirosia is a small genus within the family Scathophagidae, which up to the the present time has comprised 4 Nearctic and 4 Palaearctic species. All species of Neochirosia develop in Veratrum spp. (Liliaceae) exclusively [Neff, 1970; Michelsen, 2007].

The terminology used for the description of the new species follows McAlpine [1981], Cumming et al. [2009], and Stuckenberg [1999].

\section{Description of new species}

\section{Neochirosia nikita sp.n.}

Figs. 1-7.

MATERIAL. Holotype $\sigma^{7}$, SERBIA: Stara Planina $\left(43.37^{\circ} \mathrm{N}\right.$ $\left.22.60^{\circ} \mathrm{E}\right), 1-8 . V .2015$, N. Vikhrev. Holotype is pinned, in excel- lent condition. Partypes: $9 \odot^{\top} \sigma^{\top}, 6$ 6 , data as for holotype. All flies were collected on Veratrum sp.

DESCRIPTION. Medium-sized flies (5.6-6.4 mm long). All setae on body and legs black.

MALE. Head. Frons matt, black, sometimes tinged with dark reddish. Fronto-orbital plate grey dusted. Parafacial and face black, with greyish reflection. Gena from reddish-brown to black, with greyish reflection. Postcranium black, grey dusted. Gena 1.5-2 times as long as width of postpedicel. Chaetotaxy: 2-3 orbital, 4-5 frontal, 1 ocellar, 1 postocellar (short, divergent), 1 inner vertical, 1 outer vertical; $2-3$ pairs of vibrissae present. Antenna black. Postpedicel rounded apically, approximately 1.5 times as long as wide. Arista short haired, exept apex, the longest setulae no longer than the greatest diameter of arista. Clypeus, proboscis and palpi black. Proboscis short and wide.

Thorax black, densely grey dusted (including mediotergite, scutellum and subscutellum). Chaetotaxy of scutum: acrostichals in two rows, dorsocentrals $2+3$, intra-alars $1+2$, supra-alars $1+2$, postpronotals 2 , notopleurals 2, postalars 2. Front of postpronotal callus and scutum with spine-like additional short setae. Proepisternum bare, without hairs at middle or on anterior part, but with 1-2 setae near lower margin. Proepimeron with 2 setae under anterior thoracic spiracle. Anepisternum covered with rare short setulae in posterior half and with 4-5 setae along posterior margin. Katepisternum with 3 setae. Scutellum with 2 strong discal scutellar and 2 apical scutellar setae, the latter about twice shorter than the discal one.

Legs. Coxae and trochanters of all legs black. Femora of all legs black, only fore femur yellowish apically. Fore tibia from almost black to yellow; fore tarsus yellow. Mid and hind tibiae black. Tarsi of mid and hind legs black, only last tarsomere often brownish. 

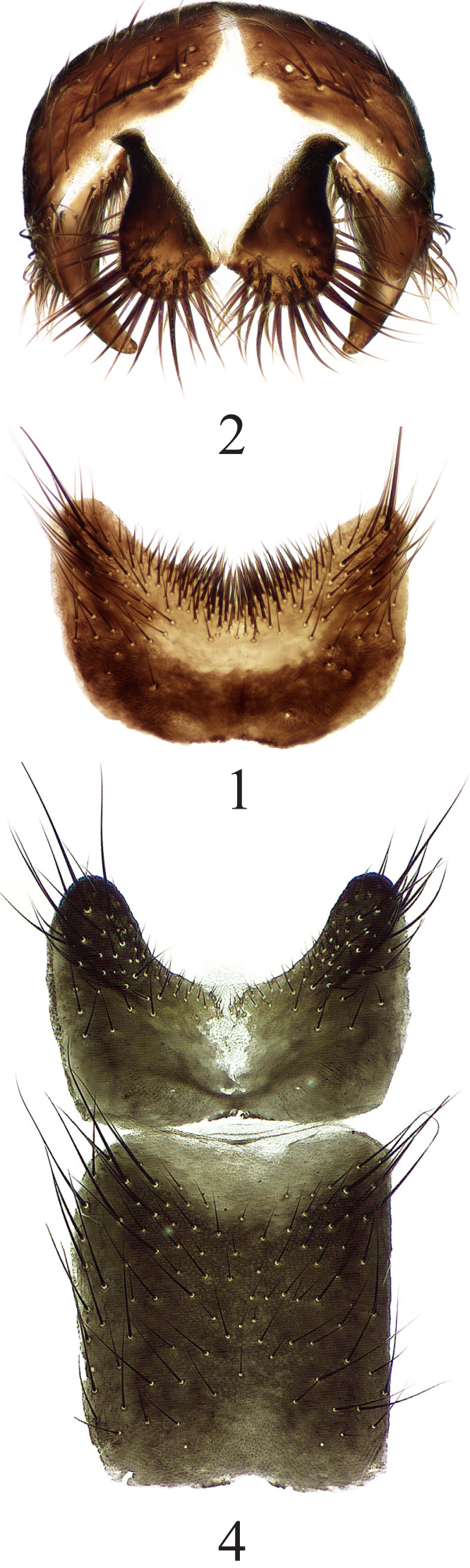
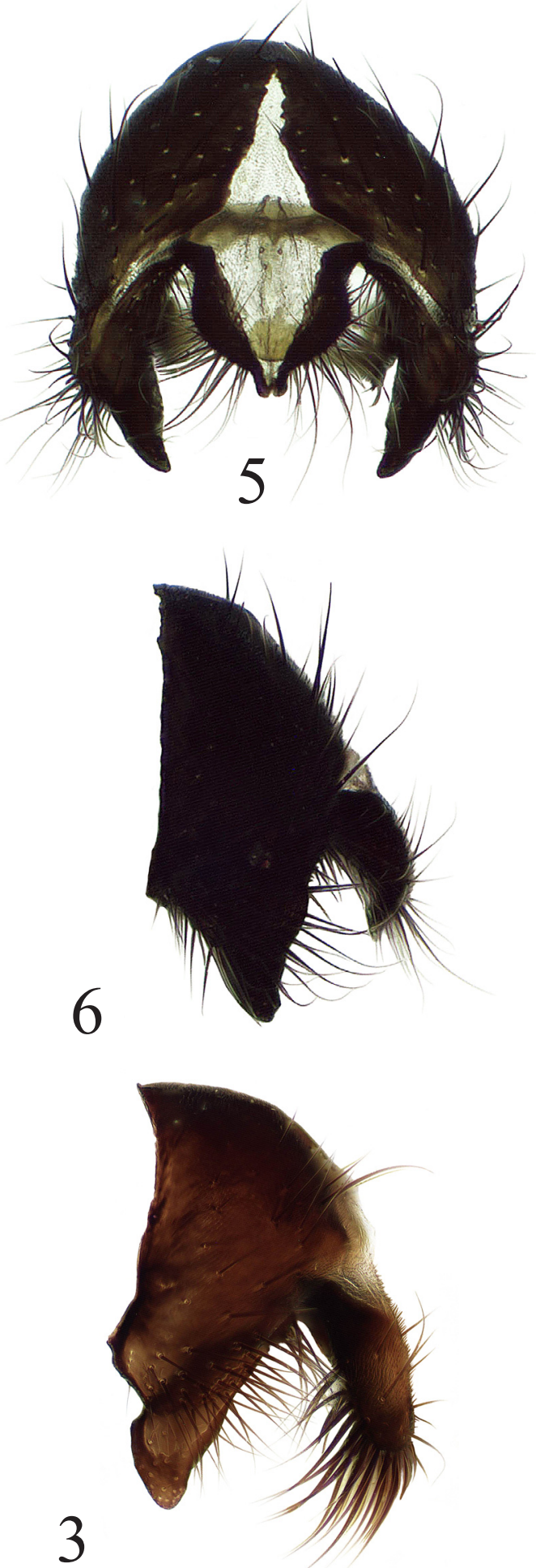

Figs 1-6. Neochirosia anthrax (Schiner, 1864) (1-3) and Neochirosia nikita sp.n. (4-6), O?: 1 - sternite 5; 2, 5 - epandrium, cerci and surstyli, dorsal view; 3, 6- same, lateral view; 4 sternites 4 (lower) and 5 (upper).

Рис. 1-6. Neochirosia anthrax (Schiner, 1864) (1-3) и Neochirosia nikita spn. (4-6), О?: 1 - стернит 5; 2, 5 - эпандрий, церки и сурстили, сверху; 3,6 - то же, сбоку; 4 - стерниты 4 (внизу) и 5 (вверху). 


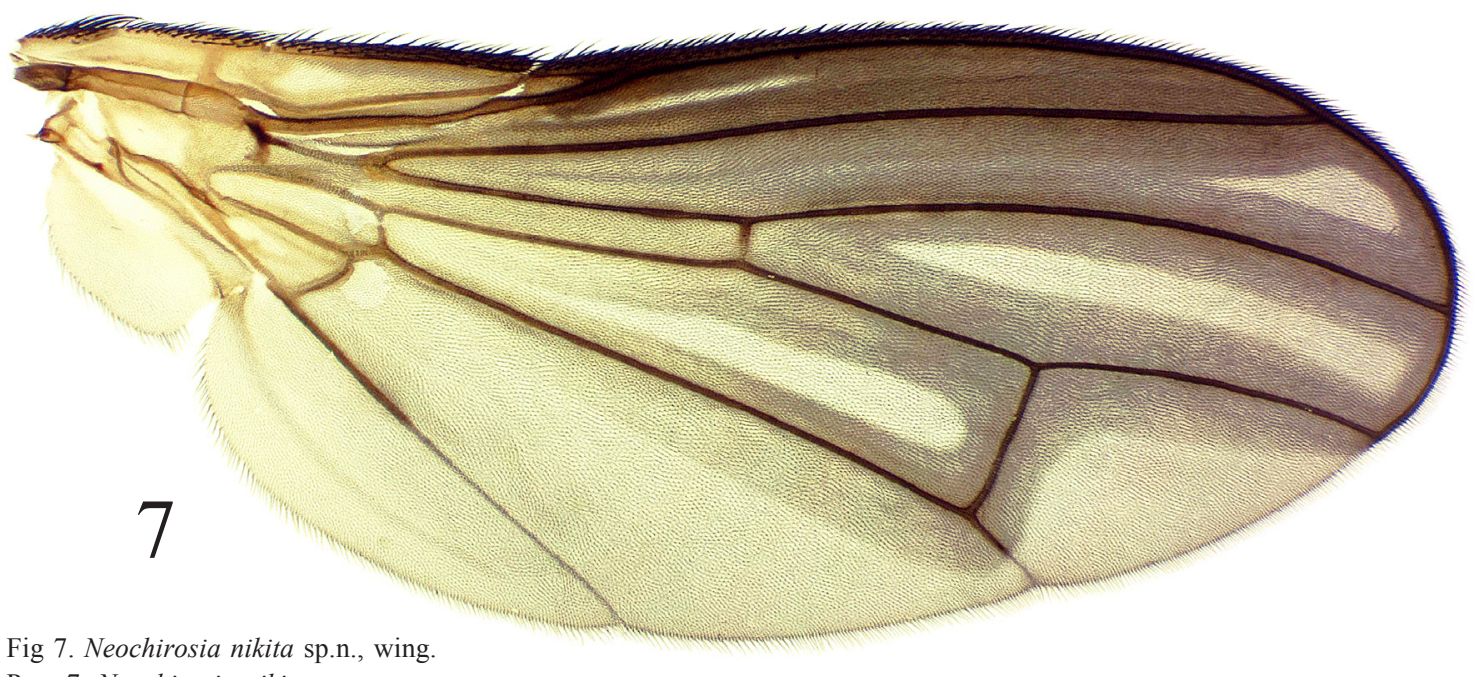

Рис. 7. Neochirosia nikita sp.n., крыло.

Fore femur with a row of posterodorsal and a double row of short spine-like posteroventral setae, in addition with 3-4 long basal posteroventral setae behind of spine-like posteroventral setae. Fore tibia with 1 dorsal and 1 posterior setae near middle, with 1 preapical dorsal seta and a ring of apical setae. Mid femur with a double row of short spine-like posteroventral setae, and in addition with 3-4 long basal posteroventral setae behind spine-like posteroventral setae, with rows of anteroventral and anterior setae, 1 preapical posterior and 1 apical posterodorsal setae. Mid tibia with 1 anterodorsal, 1 posterodorsal and $0-1$ posterior setae near middle, with preapical dorsal seta and a ring of apical setae. Hind femur with rows of anterodorsal and anteroventral setae, with 1-2 anterior setae in apical quarter, 1 preapical posterodorsal seta, and with numerous hairs on posteroventral surface. Hind tibia with 2 posterodorsal, 2 anterodorsal, 2-3 anteroventral, 1 preapical dorsal setae, with numerous hairs on posterior surface and a ring of apical setae, including posteroventral seta.

Wing 4.8-5.8 mm long, yellowish in basal quarter and blackish in other part, sometimes with clear area between veins (Fig. 7); veins blackish. $\mathrm{R}_{1}$ bare. Calypters, margins of calypters, and halteres yellowish.

Abdomen black, densely grey dusted, covered with black setulae. Tergites 1-5 each with lateral and marginal setae. Sternites 4 and 5 as in Fig. 4. Epandrium black. Cerci and surstyli as in Figs 5, 6.

FEMALE. Fore femur without a row of spine-like posteroventral setae, instead has a row of long setae. Mid femur without a row of spine-like posteroventral setae. Mid tibia with 1 ventral seta near middle. Hind femur without numerous hairs on posteroventral surface. Hind tibia without numerous hairs on posterior surface.

ETYMOLOGY. The species is named in honour of my friend and colleague Nikita E. Vikhrev, who collected the type material of this species.

COMPARISON. The new species is similar to Neochirosia anthrax (Schiner, 1864), but is readily distin- guished from this species by structure of male sternite 5 and genitalia. $N$ anthrax has sternite 5 with numerous hairs in middle part (Fig. 1), whereas these hairs are lacking in the new species (Fig. 4). Cercus of $N$. anthrax is wide apically, with numerous strong setae (Figs 2, 3); cercus of $N$. nikita is narrow apically (Figs 5,6).

TAXONOMIC NOTES. Sifner [2012] proposed a separate genus, Mirekiana Šifner, 2012, for Neochirosia anthrax. In our opinion, establishing a separate genus for $N$. anthrax is completely groundless, since diagnostic characters of that genus can be found in other species of Neochirosia, e.g. Neochirosia nigripes Becker, 1894 or Neochirosia veratri (Hendel, 1925). Therefore we describe the new species in Neochirosia and consider the name Mirekiana Šifner, 2012 to be a new junior synonym of Neochirosia Malloch, 1917, syn.n.

\section{DISTRIBUTION. Serbia.}

\section{References}

Cumming J.M., Wood D.M. 2009. Adult morphology and terminology. // Brown B.V., Borkent A., Cumming J.M., Wood D.M., Woodley N.E., Zumbado M. (eds.). Manual of Central American Diptera. Ottawa: National Research Council Press. Vol.1. P.9-50.

McAlpine J.F. 1981. Morphology and terminology-adults. // McAlpine J.F., Peterson B.V., Shewell G.E, Teskey H.J., Vockeroth J.R., Wood D.M. (coordinators). Manual of Nearctic Diptera. Vol.1. Ottawa: Research Branch. Agriculture Canada. Monograph 27. P.9-63.

Michelsen V. 2007. The identity of Chirosia cepelaki Teschner, 1978 (Diptera: Anthomyiidae \& Scathophagidae) // Genus. Vol.18. P.503-506.

Neff S.E. 1970. Observations on the life cycle and immature stages of Neochirosia atrifrons (Diptera: Scatophagidae) // Canadian Entomologist. Vol.102. P.1088-1093.

Šifner F. 2012. Mirekiana gen. nov., a new genus of dung flies (Diptera: Scathophagidae) from the Czech Republic // Journal of the National Museum (Prague), Natural History Series. Vol.181. No.3. P.15-19.

Stuckenberg, B.R. 1999. Antennal evolution in the Brachycera (Diptera), with a reassessment of terminology relating to the flagellum // Studia Dipterologica. Vol.6. S.33-48. 